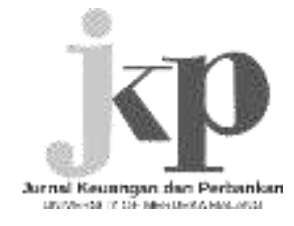

\title{
Comparative Analysis of Good Corporate Governance Implementation Based on ASEAN Corporate Governance Scorecard from the Indonesian Banking Industry
}

\author{
Ramsey Ramli ${ }^{*}$, Erna Setiany ${ }^{2}$ \\ 1,2 Department of Accounting, Faculty of Economics and Business, Universitas Mercu Buana, \\ Indonesia \\ *Corresponding Author: ramsey.ramli@gmail.com
}

\begin{abstract}
The phenomenon of Good Corporate Governance (GCG) implementation in Indonesia is still lagging compared to the other countries in the ASEAN region. For the first time, Indonesia only placed 2 (two) issuers from the banking industry as the ASEAN Top 50 publicly listed companies in the event of Awards and Recognition of Top ASEAN Publicly Listed Companies in 2015. This study aims to analyze significant difference of the GGG implementation among the Top 50 and non-Top 50 ranked banks using ASEAN Corporate Governance Scorecard (ACGS) index and its correlation with the human resources (HR) policies. The data analysis of this study uses descriptive and nonparametric comparative analyses with the Mann-Whitney test method. Despite some limitations, the empiric results showed that there are significant differences in the implementation of the GCG among the Top 50 and non-Top 50 ranked banks as proxied by the total score of the ACGS. On the contrary, there are no significant differences in the HR policies as proxied by the ACGS score on the Role of Stakeholders.
\end{abstract}

Keywords

: ASEAN Corporate Governance Scorecard; ACGS; Good Corporate Governance; GCG; Human Resources Policy; HR

JEL Classification : G21, G24

\section{INTRODUCTION}

A bank is an institution that functions as an intermediary between parties with excess funds and parties in need of funds, smoothing the flow of payments where its activities aim to improve the standard of living of the people so that banks have an important role in the economy of a country.

Banking management must be carried out carefully so that stakeholders and shareholders can get the maximum benefit. Good management of a bank or company is better known as good corporate governance (GCG). According to Sedarmayanti (2012), good corporate governance is a system, process, and set of regulations that regulate the relationship between various interested parties, especially in the narrow sense, the relationship between shareholders, the board of commissioners and the board of directors 
for the achievement of organizational goals.

Since Indonesia has undertaken corporate governance reforms through the development of a corporate governance roadmap, the corporate governance framework in Indonesia has moved gradually by adopting best practices. The corporate governance road map was developed based on the principles of the Organization for Economic Co-operation and Development or OECD (2015) regarding the corporate governance framework, protection of shareholder rights, the role of stakeholders, disclosure and transparency, and board responsibilities. The main objective of this road map is as a milestone to improve the implementation of corporate governance practices in Indonesia (ASEAN Corporate Governance Experts, 2017).

Several new regulations and / or amendments to existing regulations have been issued by the Financial Services Authority or the Financial Services Authority (OJK) as a consequence of the road map. A better regulatory framework is needed to meet international standards, such as those set out in the Association of Southeast Asian Nations (ASEAN) Corporate Governance Scorecard (ACGS). To measure improvements in the implementation of corporate governance and how corporate governance reforms have contributed to improved implementation, the ACGS assessment is used (ASEAN Corporate Governance Experts, 2017).

The Financial Services Authority (OJK) assesses that the implementation of GCG in Indonesia in ASEAN region is still lagging behind four countries, namely Thailand, the Philippines, Singapore and Malaysia (OJK, 2017). Based on a report from the Asian Corporate Governance Association or ACGA (2018), Indonesia only ranks 12, with a value of 34, after the Philippines. Table 1.1 below illustrates this:

Table 1. 2018 Corporate Governance Score Rankings

\section{ACGA Market CG Scores}

\begin{tabular}{lcl}
\hline Market & Total (\%) & \multicolumn{1}{c}{ Key CG reform themes and questions } \\
\hline $\begin{array}{l}\text { 2. Hontralia } \\
\text { 3. Singapore }\end{array}$ & 71 & Bank governance needs overhaul, time for a federal ICAC \\
Going backwards on DCS, about to go forwards on audit regulation \\
4. Malaysia & 58 & $\begin{array}{l}\text { Going backwards on DCS, reform direction reflects contradictory } \\
\text { idea }\end{array}$ \\
5. Taiwan & 56 & Moving forward, yet piecemeal reforms hinder progress \\
6. Thailand & 55 & $\begin{array}{l}\text { Moving forward, yet corruption and decline in press freedom are } \\
\text { concerns }\end{array}$ \\
7. India & 54 & Bank governance needs overhaul, new audit regulator disappoints \\
8. Japan & 54 & Heavy focus on soft law needs to be balanced with hard law reforms \\
9. Korea & 46 & Stewardship code gaining traction, but sadly so in DCS \\
10. China & 41 & Reinforcement of Party Committees raises numerous questions \\
11. Philippines & 37 & CG reform low on the government's priorities, direction unclear \\
12. Indonesia & 34 & CG reform low on the government's priorities, direction unclear
\end{tabular}

Source: ACGA and CLSA Limited (2018)

Knowing this situation, Hadad (2017) as the Chairman of the Board of Commissioners of the OJK from 2015 to 2017 has stated that there are many things need to be considered by today's business world in terms of developing corporate governance. One 
of them is the development of the quality of human resources (HR). Quality human resources and the application of good GCG principles will ensure business continuity and national economic development.

To measure the quality of human resources, the United Nation Development Program (UNDP) calculates the Human Development Index (HDI) and ranks all countries in the world. Based on the UNPD report (2019), the HDI score for Indonesia is 0.707, ranking 111 out of 189 countries assessed. The same rank is held by the State of Samoa.

Therefore, the development of the quality of human resources is very crucial to be carried out, one of which is by increasing the competence of human resources. The competency factors will shape abilities, skills and knowledge that will affect directly or indirectly the performance of a person in doing work, so that it will further improve the performance of the company's governance.

Based on the aforementioned phenomenon, the authors are interested to conduct further research related to the implementation of GCG and the development of human resources in the organization which is implemented by issuing the human resources (HR) policies. The companies studied were issuers from the banking sector because for the first time since the participation in 2012 (ASEAN Corporate Governance Experts 2017), Indonesia only placed 2 (two) public listed companies (issuers) that were included in the top 50 listed ASEAN-ranked issuers in the event of Awards and Recognition of the Top ASEAN Publicly Listed Companies 2015.

In this study, the authors will further analyze a). Are there any significant differences in the implementation of GCG among the banks that are ranked in the Top 50 and the nonTop 50 of the ACGS? b) Are there any significant differences in the HR policies among the banks that are ranked in the Top 50 and the non-Top 50 of the ACGS?

\section{HYPOTHESES DEVELOPMENT}

The agency theory underlies the concept of good corporate governance (GCG). Sutedi (2012) argued that agency theory emphasizes the importance of shareholders to handover company management to the professional so-called agents who have better understanding in running the company's daily business. These professionals are tasked for the interests of company and have the full authority to carry out the management of company, whom in this case act as the agents of the shareholders. He further argued that the corporate governance will provide assurance that the management will perform their best for the interest of the company. Hence, Zarkasy (2019) also concluded that the GCG aims to ensure the management's actions are always directed toward improving the company's sustainable performance.

According to Sedarmayanti (2012), GCG is a system, process and a set of regulations that regulate the relationship between various interested parties, specifically, the relationship between shareholders, the board of commissioners, and the board of directors, which solemnly aim to achieve organizational goals. Meanwhile, according to the OECD (2015), GCG is a structure in which stakeholders, shareholders, commissioners, and managers formulate company goals and mean to achieve these goals and supervise its performance. 
One of the GCG's scorecards used in the region is the ASEAN Corporate Governance Score Card (ACGS). The ACGS is a scorecard of the GCG assessment and rating for public companies in ASEAN. This scorecard is a regional initiative from the ASEAN Capital Market Forum (ACMF) in collaboration with the Asian Development Bank (ADB) since 2011 (ASEAN Corporate Governance Experts, 2017). The ACGS framework adopts five GCG principles of the OECD namely, Part A: Rights of Shareholders; Part B: Equitable Treatment of Shareholders; Part C: Role of Stakeholders; Part D: Disclosure and Transparency; and Part E: Responsibilities of the Board.

According to the ASEAN Corporate Governance Experts (2017), "The use of two levels of scoring is designed to better capture the actual implementation of the substance of good corporate governance. Level 1 comprises descriptors or items that are, in essence, indicative of the laws, rules, regulations, and requirements of each ASEAN member state and the basic expectations of the OECD principles. Level 2 consists of bonus items reflecting other emerging good practices and penalty items reflecting actions and events that are indicative of poor governance." Therefore, the ACGS total score used to measure company's implementation of the GCG is the total score of Level 1 and Level 2 which the maximum attainable score is 126 points.

All ASEAN companies scoring above or $75 \%$ of the total attainable score will be recognized in alphabetical order (Singapore Institute of Directors, 2019). In 2015, two issuers from the banking industry in Indonesia were successfully ranked in the Top 50 in the ACGS for the first time in ASEAN region.

Sulastri et al., (2018) stated in their research that companies who had higher score in ACGS reflects its higher implementation level of the GCG principles. Lukviarman and Johan (2018) stated in their research that higher score of corporate governance perception index (CGPI) measures indicated better implementation of corporate governance practices of a company within its environment. Nurharjanto et al., (2018) stated in their research that corporate governance (CG) index is needed to conduct a valuation of the CG implementation in the company. Wahyudin and Solikhah (2017) stated in their research that the CG rating could improve company's performance. Albeit Setiyawati and Basar (2017) had stated in their study that implementation of the GCG has no effect on company's performance. From such findings therefore, formulation of the hypothesis is as follows:

H1: There is a significant difference in implementation of the GCG among the banks that are ranked as Top 50 and non-Top 50 in the ACGS.

According to Sukirno (2017), the HR is defined as people in the organization who contribute thoughts and do various types of work to achieve organizational goals. Martin and Golan (2012) linked the GCG and HR in their study that is after the global financial crisis, the shareholder's value is more in line with the senior leadership, hence the organizational climate and the HR department strategy is much more consistent with the corporate governance regime. In addition, the research conducted by Oyewunmi et al., (2017) has shown that there is an influence of good corporate governance on the HR-related policy outcomes. The GCG should increase the effectiveness of the HR management, so that employee's satisfaction, commitment, loyalty, and bounds will also increase. While Irvan et all., (2017) stated in their research that human resource competencies directly influence positively and significantly related to good governance. 
The HR policies are measured from the scores in Items C.3 and C.4 of the ACGS. Item C.3 consists of the role of stakeholders to improve performance, development, and involvement of the employees in the company. Item C.4 consists of the freedom for stakeholders and employees to communicate illegal and unethical practices within the company and is provided with protection for such actions. Therefore, formulation of the hypothesis as follows:

$\mathrm{H}_{2}$ : There is a significant difference in HR policies among the banks that are ranked as Top 50 and non-Top 50 in the ACGS.

\section{METHOD, DATA, AND ANALYSIS}

This study is a quantitative research with comparative research approach. According to Nazir (2017), comparative research is a type of descriptive research that seeks to find answers fundamentally about cause-and-effect, by analyzing the factors that cause the occurrence or appearance of a certain phenomenon. While, according to Sugiyono (2014) a comparative research is a research that compares conditions of one or more variables within two or more different samples, or within two different times.

The population in this study is fifteen (15) issuers from the Indonesian banking industry who participated in the ACGS. The two (2) banks namely PT Bank Danamon Indonesia Tbk. and PT Bank CIMB Niaga Tbk. were ranked for the first time in the Top 50 of the ACGS in 2015. While the rest of thirteen (13) other banks were ranked in the non- Top 50 of the ACGS. The observation is conducted within the span of three (3) years from 2013 to 2015 except one bank had only one (1) year recent participation. This study uses saturated sampling technique. Saturated sampling uses all populations as the sample. Hence the total sample is fifteen (15) issuers within the total time-series observations of forty-three (43) all together.

This study uses archival data collection technique, in the form of secondary data which were obtained with the permission of the Indonesian Institute for Corporate Directorship (IICD). IICD is a non-profit organization appointed by the OJK as the Domestic Ranking Body of the ASEAN Corporate Governance Scorecard (ACGS) in Indonesia from 2013 to 2015 (IICD, 2015).

The data analysis in this study uses descriptive and nonparametric comparative analyses utilizing the Mann-Whitney test method. The Mann-Whitney test is used if the data are not normally distributed on two unrelated samples. For this study, the sample size is fifteen (15) issuers that are not related to each other, so the data is expected not distributed normally.

According to Sujarweni (2015), the decision making for the results using MannWhitney's parameters to test the hypothesis are as follow: a.) If the value of a $<0.05$, then, there are differences between the two groups; b.) If the value of $a>0.05$ then, there are no differences between the two groups.

\section{RESULTS}

The results of descriptive statistics analysis for implementation of the GCG among the banks that are ranked as Top 50 and non-Top 50 in the ACGS are summarized in the graph as follows: 


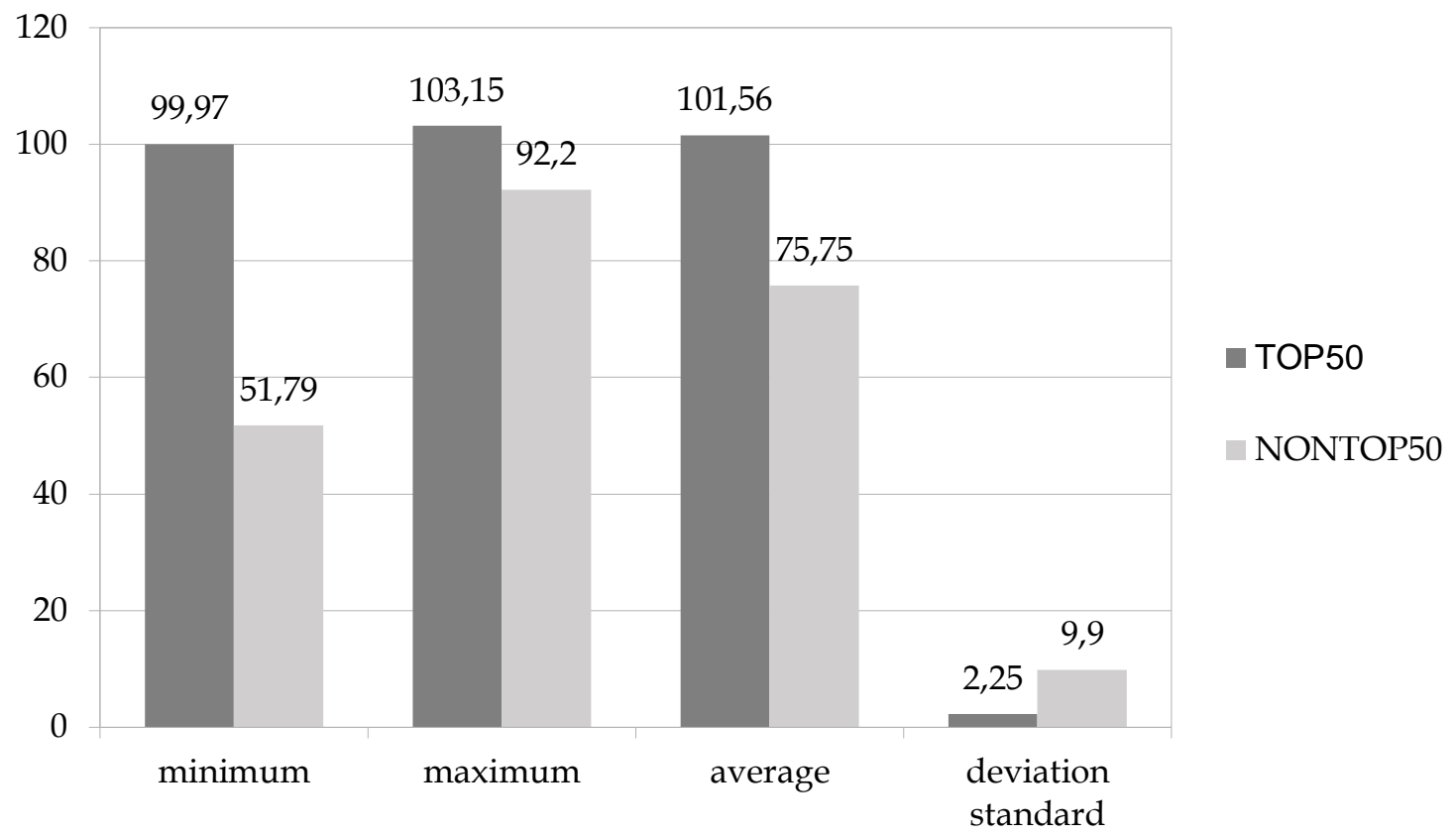

Figure 2: Total ACGS Score for the GCG Implementation

Total ACGS score for the GCG implementation of the Top 50 has a minimum value equal to 99.97, maximum value equal to 103.15, average value equal to 101.56 and standard deviation value equal to 2.25. The minimum total ACGS score of 99.97 was achieved by PT Bank CIMB Niaga, Tbk. in 2015, while the highest to tal score was achieved by PT Bank Danamon Indonesia, Tbk. also in 2015. The average of 101.56 indicates a high ACGS score. While the standard deviation value of 2.25 indicates a relatively small data deviation because it is smaller than its average value.

Total ACGS score for the GCG implementation of the non-Top 50 has a minimum value equal to 51.75 maximum value equal to 92.2 , average value equal to 75.75 and standard deviation value equal to 9.9. The minimum total ACGS score of 51.73 was achieved by PT Bank Mega Tbk. in 2014, while the maximum total score was achieved by PT Bank Tabungan Negara (Persero) Tbk. in 2015. The average of 75.75 indicates a medium ACGS score. While the standard deviation value of 9.9 showed that the data deviation is relatively small, because it is smaller than its average value.

The results of descriptive statistics analysis for the HR policies among the banks that are ranked as Top 50 and non-Top 50 in the ACGS are summarized in the graph as follows: 


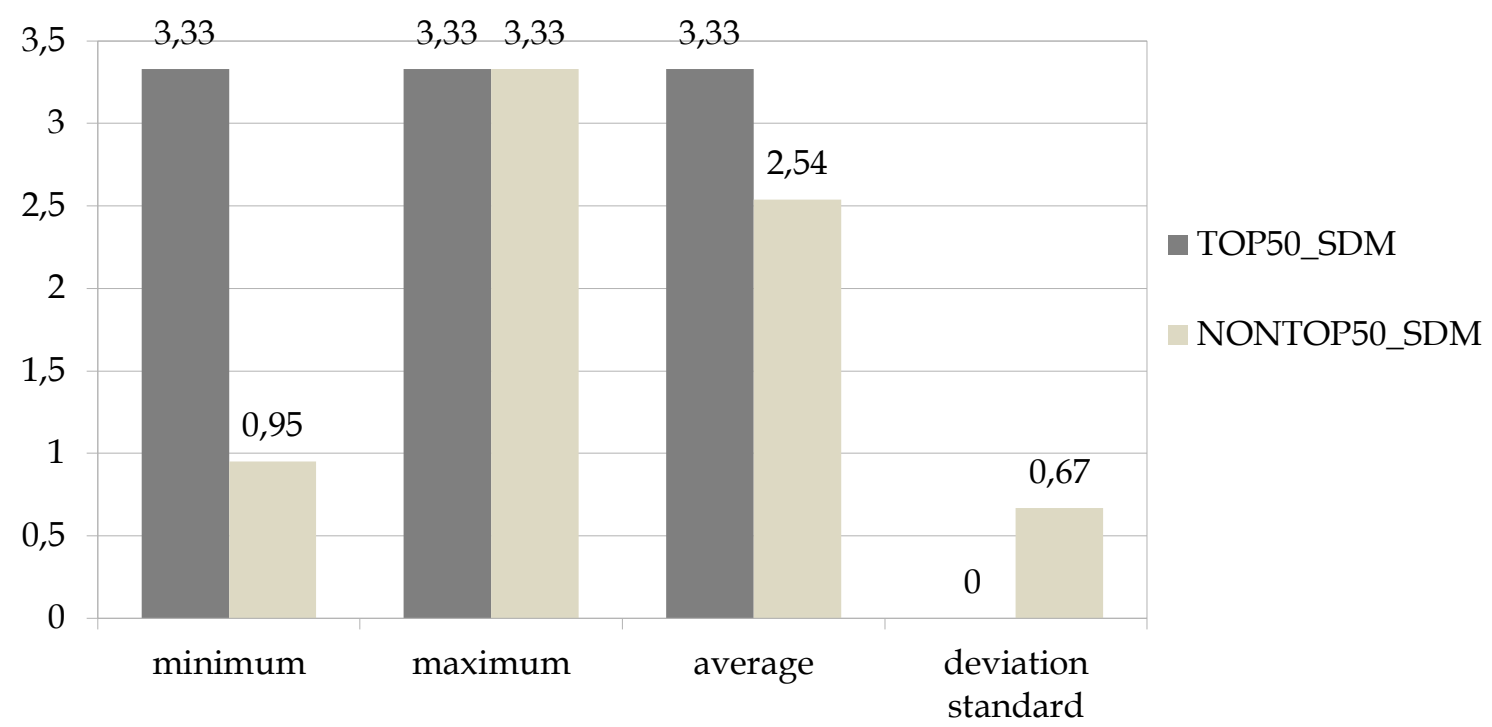

Figure 3: ACGS Score for HR Policy

ACGS scores of Item C.3 and Item C.4 for the HR Policy of the Top 50 have maximum value equal to 3.33 and were both achieved by PT Bank Danamon Indonesia, Tbk. and PT Bank CIMB Niaga, Tbk. in 2015. This is the maximum value can be obtained for disclosing the HR policies in the ACGS.

The ACGS score of Item C.3 and Item C.4 for the HR Policy of the Non-Top 50 has a minimum value equal to 0.95 , maximum value equal to 3.33 , average value equal to 2.54 and standard deviation value equal to 0.67 . The minimum score of 0.95 were shared by PT Bank Mega Tbk. and PT Bank Pan Indonesia Tbk. in 2013. While the maximum score of 3.33 which is the maximum value obtained for disclosing the HR policies in the ACGS was achieved respectively by PT. Bank BCA Tbk. in 2013, 2014 and 2015, PT. Bank Rakyat Indonesia (Persero) Tbk., PT. Bank Tabungan Negara (Perseros) Tbk., PT Bank Danamon Indonesia Tbk., PT Bank CIMB Niaga Tbk. and PT. Bank International Indonesia Tbk. in 2014, PT. Bank Mandiri (Persero) Tbk. and PT Bank OCBC NISP Tbk. in 2015. The average of 2.54 indicates a high ACGS score for the HR policies. While, the standard deviation value of 0.67 showed that the data deviation is relatively small, because it is smaller than its average value.

The following table summarizes the output of comparative analyses using the MannWhitney test on the total score of the ACGS for implementation of the GCG among the banks that are ranked as the Top 50 and the non-Top 50 in the ACGS:

Table 2. Ranks and Results of the Mann-Whitney Test for the Difference Implantation of the GCG Among the Banks that are Ranked as the Top 50 and the Non-Top 50 ACGS.

\begin{tabular}{lcccccccc}
\hline & Mean Rank & Sum of Ranks & Mann & $\begin{array}{c}\text { Asymp } \\
\text { ASEAN Corporate Governance }\end{array}$ \\
$\begin{array}{l}\text { Scorecard (ACGS) Scores Comparison } \\
\text { Top }\end{array}$ & 50 & $\begin{array}{c}\text { Non- } \\
\text { Top50 }\end{array}$ & $\begin{array}{c}\text { Top } \\
50\end{array}$ & $\begin{array}{c}\text { Non- } \\
\text { Top50 }\end{array}$ & $\begin{array}{c}\text { Whitn } \\
\text { ey U }\end{array}$ & $\begin{array}{c}\text { Sig. } \\
(2- \\
\text { tailed) }\end{array}$ & $\begin{array}{c}\text { Signif } \\
\text { icant } \\
<0.05\end{array}$ \\
\hline $\begin{array}{l}\text { Total Score of ACGS for } \\
\text { Implentation of the Good Corporate }\end{array}$ & $\mathbf{4 2 . 5 0}$ & $\mathbf{2 1 . 0 0}$ & $\mathbf{8 5 . 0 0}$ & $\mathbf{8 6 1 . 0 0}$ & $\mathbf{0 . 0}$ & $\mathbf{0 . 0 1 8}$ & Yes \\
\hline
\end{tabular}




\begin{tabular}{|c|c|c|c|c|c|c|c|}
\hline \multicolumn{8}{|l|}{ Governance (GCG) } \\
\hline \multicolumn{8}{|l|}{ ACGS Scores Per-Parts } \\
\hline Part A: Rights of Shareholders & 39.75 & 21.13 & 79.50 & 866.50 & 5.5 & 0.040 & $\mathrm{Yes}^{*}$ \\
\hline $\begin{array}{l}\text { Part B: Equitable Treatment of } \\
\text { Sharehoders }\end{array}$ & 41.50 & 21.05 & 83.00 & 863.00 & 2.0 & 0.024 & Yes $^{* 3}$ \\
\hline Part C: Role of Stakeholders & 38.50 & 21.20 & 77.00 & 869.00 & 8.0 & 0.054 & No \\
\hline Part D: Disclosure and Transparency & 42.50 & 21.00 & 85.00 & 861.00 & 0.0 & 0.018 & Yes $^{* 1}$ \\
\hline Part E: Responsibilty of the Board & 42.25 & 21.01 & 84.50 & 861.50 & 0.5 & 0.019 & Yes $^{* 2}$ \\
\hline Level 1: Total Score for Parts A to E & 42.50 & 21.00 & 85.00 & 861.00 & 0.0 & 0.018 & Yes \\
\hline Level 2: Bonus dan Penalty & 39.00 & 21.17 & 78.00 & 868.00 & 7.0 & 0.047 & Yes \\
\hline
\end{tabular}

(Source: IICD's data processed by SPSS-22. 2020)

Based on Man-Whitney test result using SPSS software for total score of the ACGS shows the Man-Whitney's coefficient is equal to 0 with significance value equal to 0.018 . Since significance value of $a(0.018)<0.05$ therefore, it can be concluded that there is significant difference in the implementation of the GCG among the banks that are ranked as the Top 50 and the non-Top 50 in the ACGS. Therefore, the hypothesis $\mathrm{H} 1$ is accepted and empirically proven.

The table also summarizes the test results for each part of the ACGS as follows:

Part A: Significance value of $a(0.040)<0.05$ therefore, there is significant difference in the right of shareholder among the banks that are ranked as the Top 50 and the non-Top 50 in the ACGS.

Part B: Significance value of $a(0.024)<0.05$ therefore, there is significant difference in the equitable treatment of shareholder among the banks that are ranked as the Top 50 and the non-Top 50 in the ACGS.

Part C: Significance value of $\alpha(0.054)>0.05$ therefore, there is no significant difference in the role of stakeholders among the banks that are ranked as the Top 50 and the non-Top 50 in the ACGS.

Part D: Significance value of $a(0.018)<0.05$ therefore, there is significant difference in the disclosure and transparency among the banks that are ranked as the Top 50 and the non-Top 50 in the ACGS.

Part E: Significance value of $a(0.019)<0.05$ therefore, there is significant difference in the responsibility of the boards among the banks that are ranked as the Top 50 and the non-Top 50 in the ACGS.

Notwithstanding, there is no significant difference in Part C, the Man-Whitney test result for total score of Level 1 has significance value of $\alpha(0.018)<0.05$ therefore, there is significant difference in the total scores from Part A to Part E among banks that are 
ranked as the Top 50 and the non-Top 50 in the ACGS.

Also, the Man-Whitney test result for total score of Level 2 of the ACGS shows significance value of $\alpha(0.047)<0.05$ therefore, there is significant difference in the total scores Bonus and Penalty among banks that are ranked as the Top 50 and the non-Top 50 in the ACGS.

In summary, the test result of total score Level 1 and Level 2 is equal to final total score of the ACGS has therefore, shown a significant difference on the implementation of the GCG among the banks that are ranked as the Top 50 and the non-Top 50 in the ACGS.

The following table summarizes the output of comparative analyses using the MannWhitney test on the total score of Item C.3 and Item C.4 of the ACGS for the HR policy of the banks that are ranked as the Top 50 and the non-Top 50 in the ACGS:

Table 3. Ranks and Results of the Mann-Whitney Test for the Difference of the HR Policy Among the Banks that are Ranked as the Top 50 and the Non-Top 50.

\begin{tabular}{|c|c|c|c|c|c|c|c|}
\hline \multirow{2}{*}{$\begin{array}{l}\text { ASEAN Corporate Governance Scorecard } \\
\text { (ACGS) Scores Comparison }\end{array}$} & \multicolumn{2}{|c|}{ Mean Rank } & \multicolumn{2}{|c|}{ Sum of Ranks } & \multirow{2}{*}{$\begin{array}{l}\text { Mann } \\
- \\
\text { Whitn } \\
\text { ey U }\end{array}$} & \multirow{2}{*}{$\begin{array}{l}\text { Asymp. } \\
\text { Sig. } \\
(2- \\
\text { tailed })\end{array}$} & \multirow{2}{*}{$\begin{array}{l}\text { Signif } \\
\text { icant } \\
<0.05\end{array}$} \\
\hline & Top 50 & $\begin{array}{l}\text { Non- } \\
\text { Top50 }\end{array}$ & Top 50 & $\begin{array}{l}\text { Non- } \\
\text { Top50 }\end{array}$ & & & \\
\hline $\begin{array}{l}\text { Total Score of ACGS Item C.3 and Item C.4 } \\
\text { for the Human Resources (HR) Policy }\end{array}$ & 37.50 & 21.24 & 75.00 & 871.00 & 10 & 0.066 & No \\
\hline \multicolumn{8}{|l|}{ ACGS Scores Per-Items } \\
\hline \multicolumn{8}{|c|}{ Item C.3: Performance-enhancing mechanisms for employee participation should be permitted to develop. } \\
\hline $\begin{array}{l}\text { Item C.3.1: The company explicitly discloses } \\
\text { the health, safety, and welfare policy for its } \\
\text { employees. }\end{array}$ & 26.50 & 21.78 & 53.00 & 893.00 & 32 & 0.461 & $\mathrm{No}^{* 3}$ \\
\hline $\begin{array}{l}\text { Item C.3.2: The company publishes data } \\
\text { relating to health, safety and welfare of its } \\
\text { employees. }\end{array}$ & 34.50 & 21.39 & 69.00 & 877.00 & 16 & 0.092 & $\mathrm{No}^{* 1}$ \\
\hline $\begin{array}{l}\text { Item C.3.3: The company have training and } \\
\text { development programmes for its employees. }\end{array}$ & 22.00 & 22.00 & 44.00 & 902.00 & 41 & 1 & $\mathrm{No}^{* 7}$ \\
\hline $\begin{array}{l}\text { Item C.3.4: The company publishes data on } \\
\text { training and development programmes for its } \\
\text { employees. }\end{array}$ & 22.50 & 21.98 & 45.00 & 901.00 & 40 & 0.825 & $\mathrm{No}^{* 6}$ \\
\hline $\begin{array}{l}\text { Item C.3.5: The company has a reward/ } \\
\text { compensation policy that accounts for the } \\
\text { performance of the company beyond short- } \\
\text { term financial measures. }\end{array}$ & 33.00 & 21.46 & 66.00 & 880.00 & 19 & 0.143 & $\mathrm{No}^{* 2}$ \\
\hline \multicolumn{8}{|c|}{$\begin{array}{l}\text { Item C.4: Stakeholders including individual employee and their representative bodies, should be able to freely } \\
\text { communicate their concerns about illegal or unethical practices to the board and their rights should not be } \\
\text { compromised for doing this. }\end{array}$} \\
\hline $\begin{array}{l}\text { Item C.4.1: The company has procedures for } \\
\text { complaints by employees concerning illegal } \\
\text { (including corruption) and unethical } \\
\text { behavior. }\end{array}$ & 24.00 & 21.90 & 48.00 & 898.00 & 37 & 0.647 & $\mathrm{No}^{* 5}$ \\
\hline $\begin{array}{l}\text { Item C.4.2: The company has a policy or } \\
\text { procedures to protect an employee/person } \\
\text { who reveals illegal/unethical behavior from } \\
\text { retaliation. }\end{array}$ & 25.50 & 21.83 & 51.00 & 895.00 & 34 & 0.528 & $\mathrm{No}^{*} 4$ \\
\hline
\end{tabular}

(Source: IICD's data processed by SPSS-22. 2020) №merical Order of the Significance Per-Items 
Based on Man-Whitney's test result using SPSS software for the total score of Item C.3 and Item C.4 of the ACGS shows Man-Whitney's coefficient is equal to 10 with significance value equal to 0.066 . Since significance value of $a(0.066)>0.05$ therefore, it can be concluded that there is no significant difference in the HR policy among the banks that are ranked in Top 50 and non-Top 50 in the ACGS. Therefore, the hypothesis $\mathrm{H} 2$ is rejected and empirically not proven.

The table also summarizes the test results for each Items C.3 and C.4 of the ACGS as follows:

Item C.3.1: Significance value of $\mathrm{a}(0.461)>0.05$ therefore, there is no significant difference in the HR policy of disclosing the health, safety, and welfare for the employees among the banks that are ranked as the Top 50 and the non-Top 50 in the ACGS.

Item C.3.2: Significance value of $a(0.092)>0.05$ therefore, there is no significant difference in publishing the HR policy of the health, safety, and welfare for the employees among the banks that are ranked as the Top 50 and the non-Top 50 in the ACGS.

Item C.3.3: Significance value of $\mathrm{a}(1)>0.05$ therefore, there is no significant difference in the HR policy on training and development programs for the employees among the banks that are ranked as the Top 50 and the non-Top 50 in the ACGS.

Item C.3.4: Significance value of $\alpha(0.825)>0.05$ therefore, there is no significant difference in publishing the HR policy on training and development programs for the employees among the banks that are ranked as the Top 50 and the non-Top 50 in the ACGS.

Item C.3.5: Significance value of $a(0.143)>0.05$ therefore, there is no significant difference in the HR policy on reward or compensation policy that accounts for the performance of the company beyond short-term financial measures among the banks that are ranked as the Top 50 and the non-Top 50 in the ACGS.

Item C.4.1: Significance value of $a(0.647)>0.05$ therefore, there is no significant difference in the HR policy on procedures for complaints by employees concerning illegal (including corruption) and unethical behaviors among the banks that are ranked as the Top 50 and the non-Top 50 in the ACGS.

Lastly, Item C.4.2: Significance value of $\alpha(0.528)>0.05$ therefore, there is no significant difference in the HR policy on policy or procedures to protect an employee or person who reveals illegal or unethical behaviors from retaliation among the banks that are ranked as the Top 50 and the non-Top 50 in the ACGS.

In summary, the test result of total score from Items C.3.1 to It e m C.4.2 of the ACGS has shown no significant difference in the HR policy among the banks that are ranked as the Top 50 and the non-Top 50 in the ACGS.

\section{DISCUSSION}

In principal, the good corporate governance (GCG) will provide assurance that the management will perform their best for the interest of the company (Sutedi, 2012) and to 
improve its sustainable performance (Zarkasy, 2019). This research has empirically proven that the banks ranked as the Top 50 in the ACGS showed better performance in the GCG implementation compared to those are the non-Top 50 banks. Such significant differences are proxied by the total score of the ACGS with an indication of the significance value of $(0.018)<0.05$. It is understood that the banks are ranks the Top 50 in the ACGS had high scores with an average value of 101.56, while the non-Top50 banks had scores in the medium category with an average value of 75.54. The minimum ACGS score for banks that are in the Top 50 is, achieved by PT Bank CIMB Niaga, Tbk. in 2015, while the maximum value achieved by PT Bank Danamon Indonesia, Tbk. also, in 2015. The average scores of the non- Top 50 banks are lower than the Top 50 banks in the ACGS. Thus, the banks ranked as the Top 50 in the ACGS are better in implementing the GCG compared to the non- Top 50 banks, amid there is no significant difference in the role of stakeholders.

Therefore, if the result of the ACGS scores is ranked per Parts then this study has empirically proven that the banks ranked as the Top 50 in the ACGS are significantly better at implementing the GCG compared to the non-Top 50 banks in the following orders namely, Part D - Disclosure and Transparency; Part E - Responsibilities of the Board; Part B - Equitable Treatment of Shareholders; and Part A - Rights of Shareholders. Only in Part $\mathrm{C}$ that is the Role of Stakeholders where the HR policy is included in it has shown no significant difference among the banks that are ranked as the Top 50 and the non-Top 50 in the ACGS. Hence this finding in Part $C$ reinforces the result of previous research by Setiyawati and Basar (2017) which stated that the implementation of the GCG has no effect on company's performance (proxied by profitability).

Nevertheless, this research empirically strengthens the results of previous studies conducted by Sulastri, et. al., (2018) which stated that companies with high ACGS scores reflect the high implementation of the GCG and is echoed by Lukviarman and Johan (2018) which stated that higher score of CGPI measures indicated better implementation of corporate governance practices of a company within its environment hence also reinforces the research by Nurharjanto et. al., (2018) which stated that a corporate governance (CG) index is needed to conduct a valuation of the CG implementation in the company and is echoed by Wahyudin and Solikhah (2017) which stated that the CG rating could improve company's performance.

On the contrary, the results of this study has empirically proven that there is no significant difference in the HR policies among the banks that are ranked as the Top 50 and the non-Top 50 in the ACGS, with an indication of a significance value of $(0.066)>0.05$. The ACGS score of the HR policies of the Top 50 banks had an average score of 3.33 which is the maximum score, while the non-Top 50 banks had an average score of 2.54, indicating a high ACGS score of the HR policy as well.

In general, Part C- Role of the Stakeholders, which includes the HR policy in it, shows that there is no significant difference in terms of performance improvement, development, and employee involvement in the company as well as in the freedom to communicate illegal or unethical practices that occur in the company. This is understandable because the banking sector is a highly regulated industry. Therefore, the HR policies at the staffing level among the banks that are ranked as the Top 50 and the non-Top 50 are strictly governed by the regulations issued by the OJK that is to have the 
same standards and level of service agreement to prudently serve their clients.

If the ACGS scores of Items C.3 and C.4 are individually ranked, the results of this study empirically has proven that there is no significant difference in the HR policies among the banks that are ranked as the Top 50 and the non-Top 50 in the ACGS in the following orders namely, Item C.3.2 - Publication of data on occupational health, safety, and welfare for its employees; Item C.3.5 - Compensation and reward policy based on company performance beyond the short-term financial measure; Item C.3.1 - Explicit disclosure of occupational health, safety policies and welfare for its employees; Item C.4.2 Policies or procedures to protect employees or persons who disclose suspected illegal or unethical behavior without any form of retaliation; Item C.4.1 - Whistleblowing policy which includes procedures for complaints by employees and other stakeholders regarding suspected illegal and unethical behavior; Item C.3.4 - Publication of data on training programs and employee development; and lastly, Item C.3.3 - Training and development programs for its employees

Although this research did not empirically prove a significant difference in the HR policies at the staffing level among the banks that are ranked as the Top 50 and the non-Top 50 in the ACGS which are proxied by the result of the ACGS scores Items C.3 and C.4 however, the results of this study relevance with previous study by Shabi, et al., (2014) which stated that effective corporate governance is all about the Board's performance. In order for the Board of Commissioners and the Board of Directors to function effectively, the members of the Boards must consist of people who are independent, talented, having a wide range of knowledge, experienced, and possess multiple perspectives in determining the GCG-based company policies.

Thus, one of the underlying phenomenon questions of this study might still be relevant that there is a significant difference in the HR policy among the banks that are ranked as the Top 50 and the non-Top 50 in the ACGS. Amid it is at the level of the Boards as proxied by the result of the ACGS score PartE.

\section{Conclusion}

Based on the results of the analysis and testing of research hypotheses presented in the aforementioned discussions, we come to the conclusions for this study are as follows: (1) There is a significant difference in the implementation of the GCG among the banks that are ranked as the Top 50 and the non-Top 50 in the ACGS; (2) There is no significant difference in the HR policies at the staffing level among the banks that are ranked as the Top 50 and the non-Top 50 in the ACGS. However, the determination of vision and mission of the HR policies at the level of the Board of Commissioners and Directors has a significant impact on theimplementation of the GCG.

\section{Limitation and Suggestions}

In conducting this research, the authors have several limitations that may be explored in future research. Those limitations are as follows:

1. The authors used the momentum of year 2015, when the first time for the issuers from Indonesia made it into the Top 50 in the ASEAN region, hence the population and sample size were limited to the issuers from the banking industry in Indonesia that had implemented the ACGS, especially during the span period of 
observation from 2013 to 2015. Thus, the sample does not represent all the issuers listed in the Indonesian Stock Exchange (IDX).

2. Due to the implementation of Large-Scale Social Restrictions during the pandemic in Jakarta, the authors could not conduct follow-up interviews with the issuers of the Top 50 banks regarding their visions and missions of the HR policies at the level of the Board of Commissioners and Directors in relation to the their responsibilities, in order to enable the authors to perform inductive data analysis.

Based on the above conclusions, some relevant suggestions are recommended for any relevant parties as follows:

1. For the issuers from Indonesia, they are recommended to implement the GCG in accordance with the ASEAN Corporate Governance Score Card (ACGS) framework that are based on the principles of the GCG issued by the OECD. By doing so, the issuers would be able to compete with the other issuers at the ASEAN regional level.

2. For the issuers from the banking industry in Indonesia, they are recommended to improve the implementation of the GCG within the framework of ACGS particularly in the Part D, i.e. Disclosure and Transparency and Part E, i.e. The Responsibilities of the Board of Commissioners and Directors. Those should be more elaborative and expressively disclosed in their annual financial reports and their other public communication means, such as company websites to showcase the quality of their GCG implementation profile in order to compete at the ASEAN region level.

3. For the issuers from the banking industry in Indonesia, they should continue improving their implementation of the HR policies at the staffing level in accordance with the GCG principles issued by the OECD within the ACGS framework, especially in the Item C.3.2, i.e. The issuer should be more elaborative and more expressive in publishing data of occupational health, safety, and welfare policies for their employees. Particularly for the Item C .3.5 on compensation and reward policies based on the company's performance beyond short-term financial measures, the issuer could introduce an internal program, such as stock ownership program where the company gives or sells its shares to employees in a limited amount known as the employee stock ownership program (ESOP) so that the HR performance can be improved, which will end result to an increase to the company's performance.

4. For future researchers, it is recommended to include all the issuers who participate in the ACGS and listed in the IDX as research population and sample to enable multi-variant analysis and make practical contributions to all the issuers from various industries.

5. For future researchers, it is recommended to conduct more in-depth study in regards to the deciding factors of the vision and mission of the HR policies at the level of the Board of Commissioners and Directors related to the responsibilities of the Board within the ACGS framework. The inductive data analysis through complementary interview with the issuers may prove that $\mathrm{such}$ vision and mission of the GCG-basedHR policies at the level of Board of Commissioners and Directors can result to an effective company's implementation of the GCG. 


\section{ACKNOWLEDGMENT}

The authors would like to acknowledge the assistance from the Indonesian Institute for Corporate Directorship (IICD) in Jakarta as the ACGS Domestic Ranking Body from 2013 to 2015 appointed by the OJK in providing the authors with relevant data of the ACGS scores from the years of 2013 to 2015.

\section{REFERENCES}

ASEAN Corporate Governance Experts. (2017). ASEAN Corporate Governance Scorecard Country Reports and Assessments 2015. Published by Asian Development Bank, Manila.

Asian Corporate Governance Association. (2018). CG Watch 2018. Hard decisions. Asia faces tough choices in CG reform. Special report. Published by ACGA and CLSA Limited, Hong Kong SAR.

Hadad, M. (2017). Tata Kelola Perusahaan Indonesia Termasuk Peringkat Bawah di Asia Tenggara. Retrieved from: https:/ / economy.okezone.com. December 15, 2018.

Human Development Report Team. (2019). Human Development Report 2019, Inequalities in Human Development in the 21st Century, Briefing note for countries on the 2019 Human Development Report. Published by United Nations Development Programme, New York.

Indonesian Institute for Corporate Directorship. (2015). IICD, Indonesian Institute for Corporate Directorship, 2015 Annual Report. Published by IICD Office, Jakarta.

Irvan, N., Mus, A.R., Su'un, M., \& Sufri, M. (2017). Effect of Human Resource Competencies, Information Technology and Internal Control Systems on Good Governance and Local Government Financial Management Performance. IRAInternational Journal of Management $\mathcal{E}$ Social Sciences, 8(1), 31-45.

Lukviarman, N., \& Johan, A. P. (2018). Meta-analysis of corporate governance in Asia. Investment Management and Financial Innovations, 15(2), 267-280.

Martin, G., \& Gollan, P. J. (2012). Corporate Governance and Strategic Human Resources Management In The UK Financial Services Sector: The Case Of The RBS. The International Journal of Human Resource Management, 23(16), 3295-3314.

Nazir, M. (2017). Metode Penelitian. Published by Ghalia Indonesia, Jakarta.

Nurharjanto, T. H., Suhardjanto, D., Lukviarman, N., \& Setiany, E. (2018). Corporate Governance, Privatisation, and Financial Performance of Indonesian Stateowned Enterprises. International Journal of Revenue Management, 10(2), 168-188.

OECD. (2015), G20/OECD Principles of Corporate Governance, Published by OECD Publishing, Paris.

Oyewunmi, O. a., Adeyemi, K. s., \& Gunnaike, O. o. (2017). Corporate Governance and Human Resource Management in Nigeria's Downstream Petroleum Sector. Economics and Business, 64(2). Scientific Annals of Economics and Business, 64(2), 139-153. 
Singapore Institute of Directors. (2019), ASEAN Corporate Governance Scorecard, Singapore Companies Briefing 2019. Retrieved from: https://www.sid.org.sg. October 21, 2020.

Sedarmayanti. (2012), Good Governance: Pemerintahan yang Baik \& Good Corporate Governance: Tata Kelola Perusahaan yang Baik. Published by Mandar Maju, Bandung.

Setiyawati, H., \& Basar, Y. S. (2017). Pengaruh pengungkapan Corporate Social Responsibility dan penerapan Good Corporate Governance terhadap tingkat profitabilitas. Jurnal Akuntansi, 21(3), 351-360.

Shabi, O. R., Bakare, I. A. O., \& Edun, A. C. (2014). HR-Corporate Governance Nexus: Implications for the Development of Nigeria's Banking Sector Services. IOSR Journal of Economics and Finance (IOSR-JEF), 3(4), 68-80.

Sugiyono. (2014). Metode Penelitian Bisnis. Published by Alfabeta, Bandung.

Sujarweni, V. W. 2015. SPSS Untuk Penelitian. Published by Pustaka Baru Press, Yogyakarta.

Sukirno, S. (2017). Pengantar Bisnis. Published by Kencana, Jakarta.

Sulastri, A., Mulyati, S., \& Icih. (2018). Analisis Pengaruh ASEAN Corporate Governance Scorecard, Leverage, Size, Growth Opportunities, dan Earnings Pressure Terhadap Konservatisme Akuntansi. Accruals. Accounting Research Journal of Sutaatmadja, 2(1), 41-67.

Sutedi, A. (2012). Good Corporate Governance, Published by Sinar Grafika, Jakarta.

Wahyudin, A., \& Solikhah, B. (2017). Corporate governance implementation rating in Indonesia and its effects on financial performance. Corporate Governance: The International Journal of Business in Society, 17(2), 250-265.

Zarkasyi, M. W. (2019), Good Corporate Governance: Pada Badan Usaha Manufaktur, Perbankan dan Jasa Keuangan lainnya. Published by Alfabeta, Bandung. 